\title{
O DIREITO DOS HUMANOS: A LIBERDADE COMO FUNDAMENTO E O GRITO MULTIFACETADO DAS RUAS
}

\author{
Sandro de Oliveira Safadi ${ }^{1}$
}

Resumo: O presente trabalho busca estabelecer inicialmente uma interface entre a noção de liberdade em Jean-Paul Sartre e a Declaração universal dos direitos humanos, tendo como pano de fundo o sentido e a conquista da cidade, pelos olhares de Henry Lefebvre, Jane Jacobs e David Harvey. Posteriormente traça aproximações e distanciamentos sobre a ocupação da rua como lugar do grito e da expressão máxima da liberdade. A dimensão empírica se instaura através da análise de entrevistas de manifestantes ou pesquisadores que estiveram envolvidos nos movimentos do maio de 1968 na França, nas jornadas de junho de 2013 no Brasil e nas manifestações dos "coletes amarelos" também na França a partir de 2018.

Palavras-chave: Liberdade; Rua; Manifestações Contemporâneas.

\section{LE DROIT DE L'HOMME: LA LIBERTE COMME FONDEMENT ET LE CRI A MULTIPLES FACETTES DES RUES}

Résumé: Le présent travail cherche à établir dans un premier temps une interface entre la notion de liberté chez Jean-Paul Sartre et la Déclaration universelle des droits de l'homme, dans le contexte du sens et de la conquête de la ville, par la vision d'Henri Lefebvre, Jane Jacobs et David Harvey. Plus tard il tire approximations et distanciamentos sur l'occupation de la rue comme lieu du cri et l'expression maximale de la liberté. La dimension empirique est établie en analysant les interviews des manifestants ou de chercheurs ayant participé aux mouvements de mai 1968 en France, aux journées de juin 2013 au Brésil et les manifestations des "gilets jaunes" également en France à partir de 2018.

Mots-clés: Liberté; Rue; Manifestations Contemporaines.

\footnotetext{
${ }^{1}$ Docente/pesquisador do Instituto Federal de Goiás, Campus Anápolis, Laboratório de Ciências Sociais e Humanidades. sandro.safadi@ifg.edu.br.

Estudos Geográficos, Rio Claro, 17: 134-159, jan./jun. 2019 (ISSN 1678-698X) http://www.periodicos.rc.biblioteca.unesp.br/index.php/estgeo
} 


\section{INTRODUÇÃO}

Em junho de 2013 lá estava eu caminhando com os jovens pelas ruas da cidade de Goiânia, diversos grupos apareciam por todos os lados engrossando as fileiras, era uma festa da cidadania, a rua nos pertencia. Eu ainda meio distante dos diálogos que eram travados pelos jovens me coloquei como cientista social, mais precisamente como geógrafo tentando entender o movimento e ao mesmo tempo interessado em saber o que significava estar nas ruas para aqueles jovens.

Os grupos possuíam extremas diferenças estéticas e comportamentais, haviam os bem penteados com roupas novas, haviam os uniformizados, haviam os vinculados aos partidos e sindicatos, timidamente aparentes, haviam os jovens do movimento estudantil, haviam professores, e também os mascarados.

Àquela altura não se sabia ainda que grupo estava no comando, até hoje não se sabe, nem se sabia para onde ir com as reivindicações, também em aberto, e em relação às táticas de rua não estava claro ainda quem eram os black blocs. Os grupos se revezavam ao microfone, as propostas de gritos de ordem eram extremamente diversas, alguns gritavam "sem violência" e logo outros respondiam ironicamente "sem moralismo", de um lado cartazes pedindo a queda do prefeito, do governador, da presidenta, e de outro, piadas com o mote central que eram os 20 centavos de aumento na tarifa de ônibus, levantando cartazes com dizeres "não é só por 20 centavos, mas 40 centavos ida e volta". A irreverência era total, músicas, cores e gritos, chamados para a rua eram feitos aos moradores dos edifícios que respondiam com palmas e novos gritos de apoio, era uma catarse coletiva.

Em uma das manifestações algo me chamou muita atenção e trago para este texto como uma das chaves interpretativas que desejo enfrentar. Em um dado momento era necessário decidir um caminho a seguir com a manifestação, um grupo desejava seguir a Assembleia Legislativa do Estado de Goiás, e o outro queria seguir a avenida que daria acesso as zonas mais nobres da cidade de Goiânia. $\mathrm{O}$ que ocorreu foi exatamente uma divisão dos grupos, para nós que escolhemos ir para a Assembleia Legislativa parecia ter ficado muito claro, o enfrentamento com a polícia iria se dar para quem escolheu ir para a porta da casa legislativa. Os mascarados se colocaram logo à frente dos manifestantes, portando capacetes, escudos de plásticos e algumas armas improvisadas, o desejo era entrar na Assembleia e a polícia não deixaria. O que se seguiu foi uma sequência de acontecimentos que se tornaram comuns no Brasil em 2013, repetindo em 2015 e 2016, enfrentamento, provocações, correria, gás lacrimogênio, spray de pimenta, cassetetes e mais correria e gritaria.

O que na manhã do dia seguinte ficou estampado nos jornais não conseguiu mostrar o que para mim havia ficado claro, a divisão dos grupos estava vinculada a divisão do próprio movimento que ocorreria já no ano seguinte. Os jovens que enfrentaram a polícia na frente da Assembleia Legislativa representam simbolicamente os mesmos jovens que em 2015 ocuparam as escolas e defenderam pautas mais libertárias. Os jovens que seguiram a avenida rumo ao lado nobre da cidade acabaram por engrossar as fileiras do pedido de Impeachment de Dilma Rousseff, presidenta do Brasil à época, e fortaleceram os movimentos de direita no Brasil, a partir do slogan "Vem pra Rua".

Não pretendo trabalhar neste texto, as variantes que se desdobraram no Brasil, talvez seja obra para outra ocasião, o que me interessa é desvendar alguns traços mais voltados para a plenitude da liberdade de se manifestar e o papel crucial da rua como lócus primordial para esta manifestação. Agregado a estas duas

Estudos Geográficos, Rio Claro, 17: 134-159, jan./jun. 2019 (ISSN 1678-698X) http://www.periodicos.rc.biblioteca.unesp.br/index.php/estgeo 
intenções vislumbro aqui também o componente diverso, espontâneo e multifacetado da tomada das ruas.

A liberdade visitada neste texto é aquela que Jean-Paul Sartre esmiuçou e definiu como algo a própria existência humana e que é definida pela escolha, pois ao escolhermos, escolhemos juntamente com a humanidade. O homem é responsável por aquilo que é, não numa simples escolha individual. A partir deste sentido de liberdade, que assume que a natureza humana não é dada anteriormente à existência é que busco os limites na Declaração Universal dos Direitos Humanos para enfrentar a temática proposta neste texto.

Posteriormente, fundamentado nas obras "O direito à cidade" de Henry Lefebvre, "Morte e vida de grandes cidades" de Jane Jacobs e "Cidades Rebeldes", de David Harvey busco dialogar com elementos inerentes as reformas urbanas, evidenciando os sentidos de higienização e gentrificação das cidades como esferas de possibilidades para desencadear ou contribuir para despertar levantes do povo e ocupação das ruas.

Para efeito analítico elejo as manifestações que assombraram Paris em 1968, o chamado Maio de 68, as Jornadas de Junho de 2013 no Brasil, e o atual levante popular na França apelidado de "Coletes Amarelos'. A empiria que trabalho neste texto foi constituída a partir da leitura e reflexão de diversas entrevistas de sujeitos que estiveram diretamente envolvidos com as manifestações, além de pesquisadores que também estiveram próximos ao que ocorreu e ocorre nas ruas, bem como relatos e testemunhos que foram divulgados anos depois, no caso do maio de 1968 e com menos distanciamento do Junho de 2013.

A preferência por estas fontes se deu exatamente pelo caráter multifacetado que são inerentes aos movimentos aqui estudados, em alguns poucos momentos recorri a obras consolidadas dos autores ao tratar do que adjetivo como "Rua insurgente". Nomes como Edgar Morin, Immanuel Wallerstein, Alain Touraine, além do próprio Jean-Paul Sartre, juntamente com Christophe Guilluy, Bemoît Coquard, Alain Badiou, Ângela Alonso, Breno Brigel e Moysés Pinto Neto, permeiam o texto ao lado de Daniel Cohn-Bendit e outros manifestantes entrevistados no calor das horas, alguns aparecem com seus nomes fictícios assim como apresentam nas entrevistas que concederam à jornais, revistas e sites.

Ao final apresento digressões que buscam pensar a rua da contestação do espírito das reformas urbanas, do transporte público, da mobilidade e da liberdade de se expressar como elementos de aproximação entre estudantes e operários, entre classes sociais por vezes distantes, vislumbrando eixos interpretativos para pensar a relação entre indivíduos sem vínculo partidário, autogestionários e afirmadores de ideais libertários.

\section{O DIREITO DOS HUMANOS E A LIBERDADE COMO REGRA}

Na Declaração Universal dos Direitos Humanos - DUDH, a palavra liberdade aparece em vinte três oportunidades, sendo que as palavras "livre, livres ou livremente" aparecem em conjunto em mais doze ocorrências. A robusta presença da noção de liberdade na DUDH ativa, entre outras interpretações, aquela de caráter ideológico característica do momento em que foi proclamada pela Assembleia Geral das Nações Unidas em Paris, em 10 de dezembro de 1948.

Declarar os direitos dos humanos em meio a perplexidade de anos de guerra foi naquele momento um salto de dignidade humana impresso com as letras da irmandade e a ausência do bloco soviético entre os países que corroboraram com a

Estudos Geográficos, Rio Claro, 17: 134-159, jan./jun. $2019 \quad$ (ISSN 1678-698X) http://www.periodicos.rc.biblioteca.unesp.br/index.php/estgeo 
declaração, em certa medida oferece toda a compreensão da amplitude do documento. A liberdade de ser e estar no mundo ultrapassou as radicais diferenças de visão de mundo inerente ao pós-guerra.

Do indivíduo ao mundo, o caminho para a liberdade foi traçado em conjunto com a elaboração de entendimentos que possibilitassem agregar e enfrentar a noção internalizada como burguesa, de que a liberdade da pessoa em sua dimensão íntima precisa passar pelo crivo de um conjunto de regras que transitam até a humanidade. Ser livre, neste contexto, é condição de existência, ser livre é munir-se de todas as condições do estar no mundo.

A DUDH, por ser um documento de extrema participação no que se refere a presença dos países, constitui-se um totem de empoderamento da Organização das Nações Unidas (ONU), entidade criada em 1945 logo após o fim da guerra. O poder aglutinador da DUDH contrasta com a dimensão por vezes individualista que transparece no documento, o que nos põem a pensar como humanos que somos, é se de fato a ONU consegue e possui estatuto diferencial para garantir o que se expressa na própria DUDH:

A Assembleia Geral das Nações Unidas proclama a presente "Declaração Universal dos Direitos do Homem" como o ideal comum a ser atingido por todos os povos e todas as nações, com o objetivo de que cada indivíduo e cada órgão da sociedade, tendo sempre em mente esta Declaração, se esforce, através do ensino e da educação, por promover o respeito a esses direitos e liberdades, e, pela adoção de medidas progressivas de caráter nacional e internacional, por assegurar o seu reconhecimento e a sua observância universais e efetivos, tanto entre os povos dos próprios Estados Membros, quanto entre os povos dos territórios sob sua jurisdição (ONU, 2017).

Em diversos momentos o que se percebe é que a dimensão estatal sucumbe a uma certa entrega da afirmação do direito do humano a sorte do indivíduo, já no Artigo $1^{\circ}$ evidencia-se a dinâmica alicerçada no indivíduo como garantidor de sua condição de liberdade. O texto do artigo expressa "Todos os seres humanos nascem livres e iguais em dignidade e em direitos. Dotados de razão e de consciência, devem agir uns para com os outros em espírito de fraternidade." Afirmar o nascimento de forma igualitária em direito e dignidade não é suficiente para garantir o que se pretende, e digo, não será o próprio documento o garantidor.

A tônica individualista perpassa também em outros artigos, o Artigo $3^{\circ}$ insiste na perspectiva abstrata de garantias, o texto diz "Todo indivíduo tem direito à vida, à liberdade e à segurança pessoal", mas não compromete o estado de forma direta e nem a própria ONU na construção desta condição. Sem querer listar os artigos, insiro aqui mais dois artigos que muito me interessam para a discussão que se seguirá, o Artigo $16^{\circ}$ que tem em seu texto a seguinte afirmativa "Toda a pessoa tem o direito de livremente circular e escolher a sua residência no interior de um Estado" e o Artigo $23^{\circ}$ que afirma que "Todo o homem tem direito ao trabalho, à livre escolha de emprego, a condições justas e favoráveis de trabalho e à proteção contra o desemprego". Nestes dois últimos artigos supracitados nota-se a presença da expressão "escolha" e aqui novamente o que se tem é uma afirmação do indivíduo, não desconsidero, no entanto, que as escolhas não são de todo desarticuladas dos universos criativos e formativos que cada indivíduo está inserindo, mas ainda é o

Estudos Geográficos, Rio Claro, 17: 134-159, jan./jun. $2019 \quad$ (ISSN 1678-698X) http://www.periodicos.rc.biblioteca.unesp.br/index.php/estgeo 
indivíduo que parece ser o responsável pela escolha de seu trabalho, algo não verificado na prática humana cotidiana.

Não estou aqui com o intuito de afirmar a negligência da ONU ao consagrar ao indivíduo o cardápio de escolhas, neste ponto a contribuição de Jean-Paul Sartre, filósofo francês extremamente ativo no momento do surgimento da DUDH, se faz como uma camada de interpretação possível do sentido de liberdade.

\section{SARTRE E A LIBERDADE: PREPARANDO PARA DESCER A RUA}

No preâmbulo da DUDH temos uma primeira consideração fundamental assim descrita "Considerando que o reconhecimento da dignidade inerente a todos os membros da família humana e seus direitos iguais e inalienáveis é o fundamento da liberdade, da justiça e da paz no mundo" e aqui proponho abrir o diálogo com Sartre com o propósito de averiguar os limites da liberdade como direito individual.

As teses centrais do existencialismo de Sartre definitivamente não cabem no objetivo geral deste texto, o que pretendo é promover uma aproximação com a noção de liberdade. Em 1945, Sartre experimentou uma situação que the trouxe espanto e percepção de sua estatura e amplitude intelectual para dialogar com as massas no pós-guerra, exatamente no mesmo fluxo histórico que desembocou na Declaração Universal dos Direitos Humanos.

$\mathrm{Na}$ noite de 29 de outubro de 1945 no Club Maintenant, criado após a libertação da França da ocupação nazista, Sartre ministrou a conferência "O existencialismo é um humanismo" com objetivos de esclarecer pontos que haviam sido questionados pelos leitores de sua obra filosófica máxima "O ser e o Nada", lançada em 1943. Ronald Aronson em seu ensaio sobre a amizade entre Jean-Paul Sartre e Albert Camus afirma que:

O sucesso do evento chocou seus organizadores. O saguão estava abarrotado de gente, e parte da multidão se aglomerava do lado de fora; Sartre pensou que eles iriam protestar quando se aproximasse. No saguão, cadeiras quebradas, mulheres desmaiadas e os corredores tão lotados que Sartre levou 15 minutos apenas para chegar ao palco (ARONSON, 2007, p. 84).

Nesta conferência Sartre tratou de explicitar os pontos em que ele sofrera as maiores críticas, entre elas aquelas que imputavam ao pensamento existencialista uma dimensão individualista, certo namoro burguês que estaria escondido por traz das convicções do pensador francês. Sartre logo de saída enfrenta esta questão, dizendo que entende o seu existencialismo como "[...] uma doutrina que torna a vida humana possível e que, por outro lado, declara que toda a verdade e toda a ação implicam um meio e uma subjetividade humana" (SARTRE, 1978, p. 4). Aqui se vale de um homem responsável por todos os homens. Sem a tentação da unificação essencial, não há natureza humana, não há aquilo que nos define anteriormente como homem para que possamos nos valer de nós mesmos. Como ele afirma, não somos um corta-papel, somos além e, como tal, existimos antes do projeto. Não podemos ser preconcebidos como um corta-papel, somos a partir de nosso impulso à vida, "o homem é liberdade", "o homem está condenado a ser livre". O homem inventa o homem na liberdade.

Estudos Geográficos, Rio Claro, 17: 134-159, jan./jun. $2019 \quad$ (ISSN 1678-698X) http://www.periodicos.rc.biblioteca.unesp.br/index.php/estgeo 
É para o homem, responsável pela humanidade, dono de sua possibilidade e, finalmente, distinto do reino material puro e simples, que Sartre pretende construir as bases de sua filosofia. Para Sartre, não é possível conceber uma verdade que não seja pelo cogito. Numa esteira de subjetividade, sua filosofia pretende esgarçar - cogito para além do indivíduo. A coisa pensante de Descartes assume outro modo. Um modo que despeja no outro a afirmação de sua condição de existência.

Neste sentido, podemos dizer que há uma universalidade do homem; mas ela não é dada, é indefinidamente construída. Eu construo o universal escolhendo-me; construo-o compreendendo o projeto de qualquer outro homem, seja qual for sua época (SARTRE, 1978, p. 17).

O homem não está preso naquilo que ele é empiricamente, mas sim num "universo da subjetividade humana", na universalidade do homem, não numa subjetividade que se encerra no psicologismo e muito menos numa natureza geral que nos faz humanos. A universalidade do homem diz respeito ao que fazemos, concretamente, como seres da universalidade. É o homem universal construindo em sua externalidade. Fora de si mesmo, ele se enfrenta como existência, se o sujeito não é um sujeito individual, porque é existência coletiva, como tal abriga a invenção do mundo.

Esta invenção não cessa, até a morte, esta invenção faz do homem covarde ou herói, para Sartre haverá sempre a oportunidade de o covarde deixar de sê-lo, não há como conceber um homem fisiologicamente covarde, ele é covarde na existência que escolheu, é covarde porque não quis em momento algum esquivar da covardia, é alguém que optou pelo limbo de não ser algo que poderia ter sido. A decisão é humana, decidir por não ser o que poderia ser é assumir uma escolha, mesmo que nesta escolha esteja escondida a não-escolha, é nesta não-escolha que o homem covarde opta por não fazer. Sua escolha reelabora a parcela da humanidade que é em sua existência covarde. Mas a qualquer momento, este homem, liberdade, pode optar por ser outro, e a humanidade pode ser outra.

Ildeu Moreira Coelho, especialista na obra de Jean-Paul Sartre ao tratar da ideia de liberdade em Sartre afirma que "Isolado, separado, por seu próprio nada, de tudo que pudesse determinar-lhe o ser, fazê-lo ser isso ou aquilo, o homem, a consciência, é indeterminação absoluta, liberdade e, enquanto tal, ao mesmo tempo, consciência de si como liberdade" (COELHO, 2003, p.90). A consciência da covardia, da apatia, ou da inércia em Sartre é distinto do que apregoa um senso restrito, ou como afirma Sartre em O ser e o Nada:

[...] o conceito empírico e popular de "liberdade", produto de circunstâncias históricas, políticas e morais, equivale à "faculdade de obter os fins escolhidos". O conceito técnico e filosófico de liberdade, o único que consideramos aqui, significa somente: autonomia de escolha (SARTRE, 1997, p. 595).

A escolha nesta perspectiva é idêntica ao fazer, um passo à frente do desejo, pois para Sartre, a liberdade, "[...] por não distinguir o escolher do fazer, nos obriga a renunciar de vez à distinção entre intenção e ato" (SARTRE, 1997, p. 595), precisamente, ao escolher, o homem atualiza o modelo de homem que em síntese qualquer homem naquele tempo pode seguir; no lugar de uma natureza humana

Estudos Geográficos, Rio Claro, 17: 134-159, jan./jun. $2019 \quad$ (ISSN 1678-698X) http://www.periodicos.rc.biblioteca.unesp.br/index.php/estgeo 
universal, como a Declaração dos Direitos Humanos faz supor, o que se tem é a responsabilidade perante a humanidade.

Sabe-se que na subjetividade que abarca a coletividade humana, a referência ao sujeito é fruto da importância concedida à escolha. Sartre afirmava que, ao escolhermos, escolhemos juntamente com a humanidade, o homem é responsável por aquilo que é, não numa simples escolha individual, pois para ele "[...] quando dizemos que o homem é responsável por si próprio, não queremos dizer que é responsável pela a sua restrita individualidade, mas que é responsável por todos os homens" (SARTRE, 1978, p. 6). A escolha autônoma é por definição uma vocação para o devir, é no mundo que se dá a existência e, por conseguinte é na escolha do ir e do vir que se manifesta o presente do humano.

Não é por acaso que Sartre irá se envolver com a rua e menos acaso ainda está no fato de Sartre se posicionar diante dos movimentos que perpassam sua existência. A rua tem um papel fundamental na afirmação da liberdade, é na rua que se encontra o conflito de classe mais agudo, é na rua que se tem o desembocar das agruras de nossas histórias, é sobre a rua que me ponho a pensar a liberdade em meio ao conflito dos direitos individuais.

\section{A RUA COMO LUGAR PARA SER LIVRE}

O homem se põe no mundo como responsabilidade fluídica, em Sartre é nesta contínua atualização da existência que se forja a liberdade, para os fins deste texto será na rua que a liberdade será visitada. Não desisti de pensar que a vida se desenrola nas ruas, apesar de aceitar as redes sociais digitais como uma esfera comunicacional viva na atualidade, vejo na rua ainda a inspiração máxima para o existir. Nas redes sociais digitais há um movimento de ir e vir da mensagem reelaborando e transformando de tal maneira que é inédito na história da humanidade, mas mesmo neste ponto a rua ainda é mais poderosa, a rua desce ao corpo, a rua explode em existência.

Todos se expressam na rua, o homem, "responsável por todos os homens", para além de sua individualidade acusa os limites da civilização ao ocupar a rua. Não é de se estranhar que Henry Lefebvre em seu célebre "Direito à cidade" irá afirmar o contraste no qual, a cidade como obra, convive de forma complexa com a irreversível orientação pelo dinheiro. Desta forma "O uso principal da cidade, isto é, das ruas, e das praças, dos edifícios e dos monumentos, é a festa" (LEFEBVRE, 2015, p.13) foi confrontado pela industrialização e tem-se que "Quando a exploração substitui a opressão, a capacidade criadora desaparece" (LEFEBVRE, 2015, p.14). É preciso buscar na rua e na praça, como lugares externos à intimidade do lar, os sentidos da existência criadora.

O poder constituído na contemporaneidade se amedronta com as redes sociais digitais, a América de Donald Trump ou o Brasil de Jair Bolsonaro são apenas dois exemplos da amplitude das redes sociais digitais no que se refere ao jogo de mensagens que servem como fermento para ascensão e queda dos líderes carismáticos. Mesmo com esta dimensão assustadoramente nova destas novas redes é na rua que se expressa o descontentamento frente a frente às forças do estado. A polícia como a expressão governamental mais próxima das ruas é o maior exemplo deste enfrentamento entre os cidadãos e o estado. Os planejadores já há muito tempo sabem da necessidade de se conquistar as ruas com suas réguas para se ter certo controle das ebulições populares nas cidades.

Estudos Geográficos, Rio Claro, 17: 134-159, jan./jun. $2019 \quad$ (ISSN 1678-698X) http://www.periodicos.rc.biblioteca.unesp.br/index.php/estgeo 
Lefebvre em sua análise sobre a reforma urbana de Paris, entre os anos de 1852 e 1870, aponta que os planos do Barão de Haussmann, seguiu uma lógica de acomodação das camadas populares que haviam se levantado em 1848 contra o regime monárquico e em nome de melhores condições de vida e trabalho. A reforma atendeu a princípios de afirmação e legitimação da burguesia, na perspectiva de conter o avanço da democracia urbana, evidenciando três grandes ciclos de acontecimentos, entendidos por Lefebvre como atos desferido por Haussmann.

Primeiro ato: Haussmann substitui as ruas tortuosas por longas avenidas, os bairros sórdidos, mas animados, foram substituídos por bairros aburguesados. Assim, os boulevards serviram para "[...] pentear Paris com as metralhadoras" nas palavras do poeta surrealista Benjamin Péret, como, lembra Lefebvre. É a ação da régua do planejamento sobre a cidade.

Segundo ato: os ricos defendem a concepção de habitat contrapondo a ideia do habitar a cidade. Esta contraposição traz a figura dos subúrbios, que foram criados para atender ao "[...] impulso cego (ainda que motivado e orientado) da industrialização" (LEFEBVRE, 2015, p. 24)

Terceiro ato: A crise da urbanização, a catástrofe, o estado não pode mais se contentar em organizar e conter a especulação imobiliária. Surgem os novos conjuntos habitacionais e as "novas cidades". A pressão por moradias faz com que mesmo as esquerdas exijam mais moradias a um custo baixo, não se elabora um sentido de direito a cidade, no máximo um direito do homem.

As reformas evidenciaram o conflito de classe, a rua passa a ser o lugar da resistência, estar na rua era em grande medida marcar posição. Neste sentido, a reforma de Paris, na visão de Lefebvre, precipitou a tomada do centro pelos operários em 1871 com o advento da comuna de Paris. Um refluxo histórico à violência urbana praticada pela criação dos boulevards à força. Outro refluxo se deu em contraposição a consolidação do espírito do habitat, com o advento do subúrbio a consciência urbana se esvai, surge um pensamento contra a cidade.

E ainda como afirmação gradual da separação de classes e a potencialização do conceito de habitat surgem as moradias dispostas em blocos de apartamentos, chamados de conjunto, onde a ideia de habitat foi levada como forma pura pela burocracia estatal e os chamados pavilhões, que eram conjuntos residenciais com casas isoladas umas das outras, que se espalharam pela periferia de Paris e devido a certa quebra da ordem do planejamento pela via de uma ampliação desordenada, se mantém com ares mais libertários. A lógica do habitat traz a ordem como premissa inviolável, em contrapartida os pavilhões despertam o desejo e estimula a convivência, na esteira dos desejos e das esperanças "[...] as pessoas dos pavilhões lamentam a ausência de uma lógica do espaço, as pessoas dos conjuntos lamentam não conhecer a alegria dos pavilhões" (LEFEBVRE, 2015, p.28). Nesta construção do imaginário das classes populares a rua se mantém como lócus da performance da liberdade, o lugar do grito. A "autonomia da escolha" que Sartre defende como sendo o cerne da liberdade, garante sua raiz perene na rua.

O exemplo de Paris não foi um caso isolado, as políticas de higienização, que retirou as classes populares das zonas centrais da cidade de Paris, reposicionando-as em locais distantes do centro, juntamente com o processo de gentrificação, que dificultou profundamente o retorno destas classes populares às zonas centrais, ocorreu como um processo e afirmação dos bons resultados do planejamento moderno.

David Harvey em sua obra "Cidades Rebeldes", afirma que em Nova York na década de 1950, com a política do macartismo avança-se sobre o urbanismo como

Estudos Geográficos, Rio Claro, 17: 134-159, jan.jun. 2019 (ISSN 1678-698X) http://www.periodicos.rc.biblioteca.unesp.br/index.php/estgeo 
estratégia de absorção do excedente de produção, desta forma é a elevação da escala do boulevard parisiense para a região metropolitana novayorquina. Entre os anos de 1955 e 1960, a escritora Jane Jacobs lidera um movimento contra a noção dominante de que era necessário destruir o passado das construções em nome do novo, e naquele momento, a disputa com o planejador referência para as cidades estadunidenses, Robert Moses, toma proporções absurdas, Harvey assim narra este momento:

Não apenas os centros das cidades se revoltaram. Os tradicionalistas mobilizaram-se cada vez mais em torno de Jane Jacobs e tentaram impor limites ao modernismo brutal dos projetos de grande escala de Moses com um tipo diferente de estética urbana centrada no desenvolvimento dos bairros locais e na preservação histórica, e, em última análise, na gentrificação de áreas mais antigas (HARVEY, 2014, p. 38).

Jane Jacobs inverte a escala de valores dos bairros mais antigos, algo que na contemporaneidade é tido como um desejo de renovação das grandes cidades. Neste sentido a Nova York de hoje possui em grande parte uma expressão de uma vitória, mesmo que parcial de Jane Jacobs, ou seja, uma vitória em alguns bairros que se mantiveram ligados ao passado, mantiveram sua arquitetura original e passaram a sofrer constantes requalificações e renovações que expressam na atualidade uma existência mais libertária.

Andar pelas ruas em contraposição ao deslocamento de automóveis foi para Jane Jacobs, e é ainda hoje, um dos maiores dilemas das cidades contemporâneas. Em sua obra "Morte e vida de Grandes Cidades" Jacobs já enfrentava este dilema, dizia ela em 1961 que os planejadores imaginavam equivocadamente que ao resolver os problemas dos automóveis iriam em cadeia resolver o problema das cidades, no sentido contrário ela lança uma pergunta provocadora, "Como saber que solução dar ao trânsito antes de saber como funciona a própria cidade e de que ela necessita nas ruas?" (JACOBS, 2017, p.6). Esta pergunta é definitiva, o acontecer nas ruas carece de olhares mais atentos, a velocidade na busca por resolver problemas de trânsito, que prevalece ainda hoje nas reformas urbanas, não parece ter conseguido arrefecer a crise urbana, e a cidade é ainda o centro do conflito de classes, a arena que nos fala Lefebvre ${ }^{2}$.

Jacobs questiona o modelo de planejamento urbano que privilegia a solução dos conflitos com o olhar voltado primordialmente ao automóvel ainda na década de 1960, daquele tempo até os dias atuais a circulação de automóveis pelas cidades assistiu um crescimento exponencial. Já em 1960 Jacobs alertava para este olhar míope dos planejadores, cita a região do Morningside Heigts que foi pensada para ser perfeita, com áreas verdes em abundância, campus, playgrounds e outras áreas livres, além de universidades renomadas, bons hospitais e igrejas. Ela ainda acrescenta, "Não tem indústrias ${ }^{3}$. Suas ruas são zoneadas com o objetivo de evitar que 'usos incompatíveis' invadam a privacidade dos sólidos e espaçosos apartamentos de classe média e alta" (JACOBS, 2017, p.4). Neste ponto as aspas utilizadas pela autora demonstram exatamente sua crítica contra a noção de

\footnotetext{
${ }^{2}$ Não estou ignorando as tentativas contemporâneas de pensar cidades sustentáveis, inteligentes e mais humanas, entretanto o conflito entre automóveis e pedestres que ainda persiste nas cidades em larga medida é a expressão do conflito de classes. Mesmo com as cidades europeias passando por grandes transformações no sentido de amenizar a relação entre automóveis e pedestres, não é algo ainda muito avançado nas cidades latino-americanas e no nosso caso específico aqui no Brasil.

${ }_{3}^{3}$ Importante ressaltar que a autora se refere ao bairro de Morningside Heigts na década de 1950.

Estudos Geográficos, Rio Claro, 17: 134-159, jan./jun. 2019 (ISSN 1678-698X) http://www.periodicos.rc.biblioteca.unesp.br/index.php/estgeo
} 
separação das atividades que os planejamentos se assentavam na década de 1950 e 1960 em Nova York fruto de uma nova roupagem da reforma de Paris do século XIX.

O Bairro de Morningside Heigts já apresentava aspectos de cortiço em 1950, "[...] do tipo no qual as pessoas sentem medo de andar nas ruas" e como afirma Jacobs a região decaiu ainda mais depressa após a tentativa de nova reurbanização, com os mesmos princípios dos planejadores, levando shoppings centers e conjunto habitacional entremeado de "[...] áreas livres, luz, sol e paisagismo" (JACOBS, 2017, p.4). Em contraposição a este modelo, Jacobs defendia a região do North End em Boston, que era tida como "uma vergonha municipal" (JACOBS, 2017, p.7). A autora relata que esteve neste bairro em $1939 \mathrm{e}$ retornou em 1959. O North End em 1959 apresentava os seguintes aspectos:

[...] a mais alta densidade habitacional de Boston, [...] poucas áreas verdes. As crianças brincam na rua. Em lugar de superquadras, ou mesmo de quadras suficientemente longas, possui quadras curtas; no jargão urbanístico, a região é "maltraçada", com ruas em excesso (JACOBS, 2017, p.7).

O que Jacobs notou em seu retorno ao bairro foram pessoas andando pelas ruas, fazendo compras, as crianças continuavam brincando nas ruas, "[...] uma atmosfera de alegria, companheirismo e bem-estar", suas impressões se transformam ao longo de seu livro em uma proposta concreta do que deveriam ser as cidades, as ruas e calçadas de uma cidade são seus órgãos mais vitais, se parecerem interessantes, a cidade parecerá interessante, uma calçada viva é uma barreira ao crime. Os olhos precisam ser voltados para a rua, estabelecimentos comerciais tornam-se lugares de passeio e contemplação, atrai as pessoas. A rua e a calçada são lugares de encontros de pessoas que não possuem intimidade, a esquina deve ser valorizada.

A variedade de atividades e de situações mantém a chama viva dos bairros e das cidades, os contatos feitos na rua despertam a identidade pública, a rua é o lugar para ser livre, exercer a plenitude do humano em nós. É sobre a rua que pretendo pensar adiante neste texto, não apenas a rua da vida cotidiana, mas a rua como lugar para expressar descontentamento e se rebelar, a rua como lugar para exercer a liberdade e para exigir ser visto.

\section{A RUA INSURGENTE, AS VOZES DE 1968, 2013 E 2018}

Antes das obras tivemos os gritos da rua, revisito aqui as vozes de pessoas comuns, intelectuais e ativistas, a partir de testemunhos de época, relatos espontâneos e entrevistas referentes a três grandes movimentos insurgentes que tiveram na rua seu lugar de fermentação. O maio de 1968 na França, as jornadas de junho de 2013 no Brasil, e o movimento dos coletes amarelos em 2018/2019 também em solo francês. A cidade e mais especificamente a rua serviram de sustentáculo para catapultar estes movimentos e adentrar a casa e as mesas de discussão em bares, além dos jornais, revistas, meios acadêmicos, empresarias, e em última instância a humanidade.

A escritora e ativista Jane Jacobs parece ter tido uma visão muito além de seu tempo, pois o que se viu em diversas cidades europeias e estadunidenses nas décadas posteriores foi exatamente um repensar do uso da rua e das calçadas.

Estudos Geográficos, Rio Claro, 17: 134-159, jan./jun. $2019 \quad$ (ISSN 1678-698X) http://www.periodicos.rc.biblioteca.unesp.br/index.php/estgeo 
Talvez Jacobs não tivesse percebido que estaria prestes a vivenciar a insurgência dos jovens pelas ruas das cidades de Nova York, Paris e diversas outras pelo mundo, algo que ocorreu no final da década de 1960. Quando questionou o modelo de cidade que para os urbanistas o bairro de Morningside Heigts seria o ideal, não havia vislumbrado que suas raízes permaneceriam sólidas ali mesmo. Já em 1968 os estudantes da Universidade de Columbia, iniciaram um levante pelas ruas em pleno Morningside Heigts, questionando entre outras coisas a construção de um ginásio monumental feito de concreto, ainda no espírito das grandes obras de Moses. Immanuel Wallerstein deixou um testemunho em 2018, quando da comemoração do quinquagésimo aniversário do levante estudantil, explicitando as duas demandas mais relevantes entre os jovens:

[...] a primeira era que Columbia deveria retirar sua afiliação ao Instituto de Análises de Defesa, que era um dos pilares do envolvimento dos EUA no Vietnã. A segunda foi que Columbia deveria interromper a construção de um novo ginásio em Morningside Park, cujo terreno era considerado por direito como da comunidade negra do Harlem, e que teria sido despejada pela Universidade de Columbia (WALLERSTEIN, 2018).

A disputa por um conceito de cidade que em Jane Jacobs era crucial para a renovação dos bairros, teria sido o componente que faltava para acender o levante estudantil. As ruas foram ocupadas prioritariamente pelos negros que na visão de Wallerstein eram mais organizados (Figura 1), o que em síntese era a ocupação e a deflagração da identidade pública que anunciava Jacobs quase uma década de antecedência.

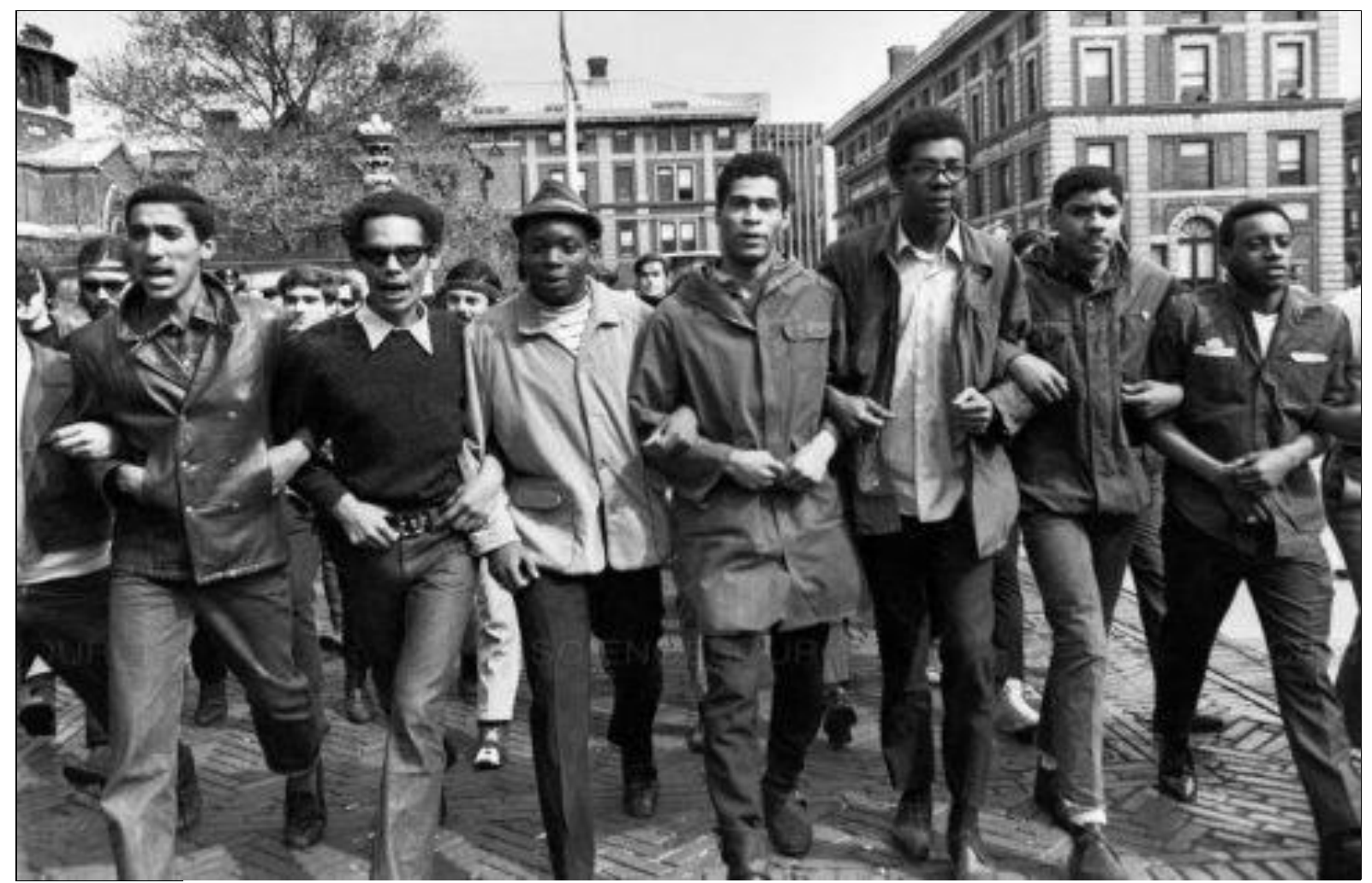

Figura 1 - Negros integrantes da SAS "Sociedade Estudantil Afro-americana" durante um protesto em maio de 1968, na Universidade Columbia.

Fonte: outraspalavras.net

Estudos Geográficos, Rio Claro, 17: 134-159, jan./jun. 2019 (ISSN 1678-698X) http://www.periodicos.rc.biblioteca.unesp.br/index.php/estgeo 
David Harvey vai assinalar que a luta pelas condições de vida não cessa com a ação organizada dos planejadores, para ele o processo de transformação e higienização enraizado na proposta de Haussmann em Paris fez despertar as revoltas que culminaram na Comuna de 1871, assim como a "[...] insipidez da vida nos subúrbios teve um papel crucial nos dramáticos movimentos de 1968 nos Estados Unidos" (HARVEY, 2014, p.39), dos quais o acontecimento da Universidade de Columbia teria sido o deflagrador, antes mesmo de estourar o maio de 1968 na França.

\title{
UM MÊS QUE REINVENTOU OS JOVENS: O MAIO FRANCÊS
}

$\mathrm{Na}$ Paris de 1968 os acontecimentos de maio chamam a atenção pela sua magnitude e também pela sua capacidade de ter atraído outras roupagens para a manifestação nas ruas. Alain Badiou, filósofo francês que também vivenciou as ruas naquela época ao fazer um balanço do movimento em 2008 para o site nonfiction.fr traça uma variação de interpretações e de alinhamento que em síntese traz chaves interpretativas para a averiguação que pretendo estender neste tópico. Para Badiou:

\begin{abstract}
Haviam quatro maio de 68, cujas temporalidades e questões eram diferentes. $O$ estudante maio de 68 , o movimento da juventude, que, como tal, era um movimento político e cultural. $O$ maio de 68 da grande greve dos trabalhadores, que tinha seus próprios padrões. Houve o maio de 68 que eu chamarei de libertário. E lá estava o maio de 68, que eu chamarei de composto, que considerava que o que estava começando ali era uma nova figura da política, constituída principalmente em torno de um novo elo entre o intelectual e o povo, que constituía um genealogia histórica e política (BADIOU, 2008).
\end{abstract}

A diversidade de pautas que se percebe com o distanciamento do tempo e com os desdobramentos históricos posteriores as ruas de Paris em 1968, não estavam muito claros desde o início. O próprio Daniel Cohn-Bendit, líder estudantil que apavorava os intelectuais e também as famílias tradicionais, em meio ao fervilhar dos dias concede uma entrevista a Jean-Paul Sartre pelo semanário Nouvel Observateur, onde ressalta uma característica do movimento que ofereceria a tônica da diversidade e ao mesmo tempo concederia solidez para atingir um segundo estágio e tomar as ruas. Indagava Cohn-Bendit na fervura dos acontecimentos:

[...] a defesa dos interesses dos alunos é algo muito problemático. Quais são os "interesses"? Eles não constituem classe. Trabalhadores e camponeses formam classes sociais e têm interesses objetivos. Suas demandas são claras e dirigidas à administração e ao governo da burguesia. Mas os estudantes? Quem são seus "opressores", se não o sistema como um todo? (COHNBENDIT, 1968).

Estas indagações do jovem revolucionário atingiria o movimento das esquerdas tradicionais, estavam ali experimentando um padrão de liberdade que nem os revolucionários tradicionais de orientação marxista podiam usufruir e também não era possível viver plenamente livre em uma sociedade burguesa Estudos Geográficos, Rio Claro, 17: 134-159, jan./jun. 2019 (ISSN 1678-698X) http://www.periodicos.rc.biblioteca.unesp.br/index.php/estgeo 
afeitada pela autoridade dos patrões, dos professores, dos pais e dos governantes. Os jovens franceses atuaram em outra perspectiva, para Cohn-Bendit o que estava em marcha era "[...] uma refutação da famosa teoria da 'vanguarda revolucionária' como a força que lidera o movimento popular", esta refutação não era exatamente programática, mas sim um misto comportamental e cultural, que almejava uma transformação social. $\mathrm{O}$ que fugia à tradição revolucionária caracteristicamente de esquerda era exatamente o papel dos estudantes que exigiam uma participação mais mundana, mais próxima da imaginação da rua, "A espontaneidade possibilita o direcionamento para frente, não as ordens de um grupo líder" (COHN-BENDIT, 1968). Edgar Morin ao realizar sua avaliação cinquenta anos após o maio de 1968, para a revista "socio" irá trazer à tona uma visão para além das esferas ideológicas convencionais, e segundo a caminhada dos jovens de 1968 aponta para outras espessuras do movimento. No início havia uma refutação ao sistema de exames e posturas dos professores nas universidades, mas para Morin "As aspirações profundas dessa adolescência neste mundo de adultos foi: mais autonomia, mais liberdade, mais comunidade" (MORIN, 2018). A liberdade e a noção de comunidade como suportes para legitimar a autonomia que os jovens exigiam só poderia ocorrer fora dos muros das universidades, e foi nesta circunstâncias que os estudantes encontraram os operários e assim o movimento tomaria outra proporção. Sartre escreveria em junho de 1968 no semanário parisiense Nouvel Observateur que "Ao velho motor das revoluções, que era a necessidade nua, veio a suceder uma exigência nova que é aquela da liberdade" (SARTRE, 1968). Não haveria para estes jovens outro lugar para exercer plenamente a liberdade que não fosse a rua (Figura 2).

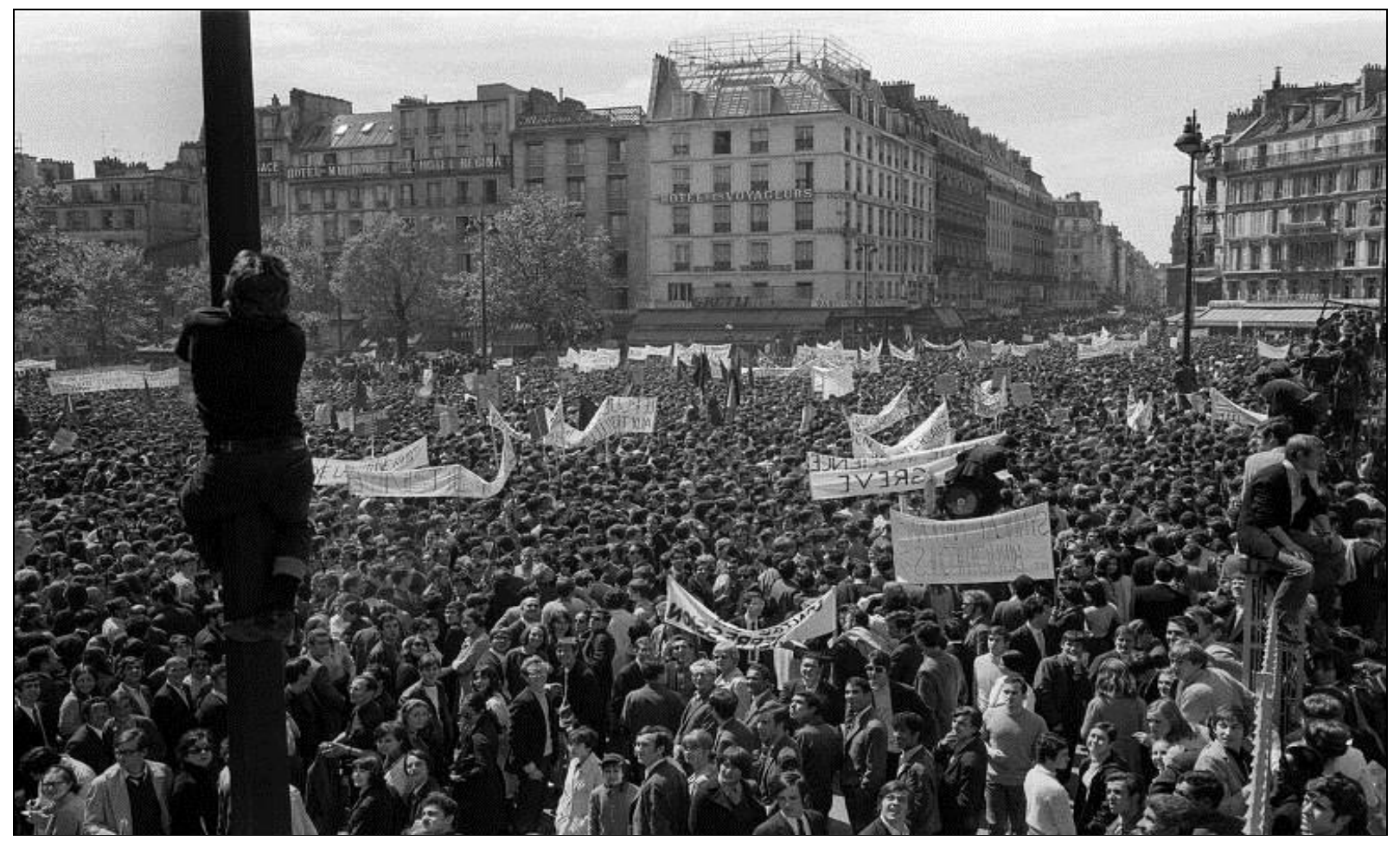

Figura 2 - Estudantes e operários juntos entre a praça La Republique e a praça Denfert Rochereau, no dia 13 de maio de 1968, greve geral.

Fonte: franceinter.fr

\footnotetext{
${ }^{4}$ Preferi manter a citação com o ano de 1968, para garantir fidelidade perspectiva de tratar as entrevistas, os testemunhos e os relatos pela data em que ocorreram. Neste caso específico esta citação se refere a obra SARTRE, J.P. LÉVY. B. O testamento de Sartre. Porto Alegre: L\&PM, 1986.

Estudos Geográficos, Rio Claro, 17: 134-159, jan./jun. 2019 (ISSN 1678-698X) http://www.periodicos.rc.biblioteca.unesp.br/index.php/estgeo
} 
Nesta medida a rua não se restringe mais a rota dos automóveis, a rua dos planejadores urbanos acusados por Jane Jacobs como sendo sem imaginação e sem alma, estaria agora naquele levante juvenil experimentando o alvorecer de novos tempos. Morin afirma, talvez com certo exagero que "Toda uma série de tendências neolibertárias resultam de 68. O feminismo não estava presente em maio de 68, mas saiu daí, o movimento dos homossexuais igualmente" (MORIN, 2018). O maio de 68 gerou entre os intelectuais confusão e despreparo para firmar posicionamento. Alain Touraine, que no momento dos acontecimentos não viu ascensão de um movimento genuinamente revolucionário, em uma entrevista, concedida ao site The Conversation em razão dos cinquenta anos do maio de 68 afirmou que "Na época, depois das barricadas do Quartier Latin, rue Gay-Lussac, por exemplo, o impacto da juventude permaneceu considerável. E o julgamento dos notáveis, incluindo os intelectuais, permaneceu dominado pelos mesmos malentendidos." (TOURAINE, 2018) e conclui com suas ressalvas ainda dizendo que "[...] o impacto político de maio de 68 permaneceu zero. Sua influência intelectual foi negativa; por outro lado, em questões sociais e culturais, tem sido e continua sendo extremamente importante". Touraine se refere aos dias 10 e 11 de maio de 1968, quando de forma inesperada e seguindo a espontaneidade do movimento dos jovens ocorre o episódio que ficou conhecido como a "noite das barricadas". Na ocasião a polícia não recuou e os estudantes passam a montar então barricadas tombando automóveis (Figura 3) em meio a uma convulsão de acontecimentos e quebradeiras. Naquele momento se transforma em uma tática de rua na manifestação. A espontaneidade é lembrada por diversas vezes nos acontecimentos de 1968, a noite das barricadas parece ter seguido o mesmo viés, mas tombar, quebrar e queimar carros em Paris tornou-se algo vinculado a dinâmica das revoltas populares na cidade luz.

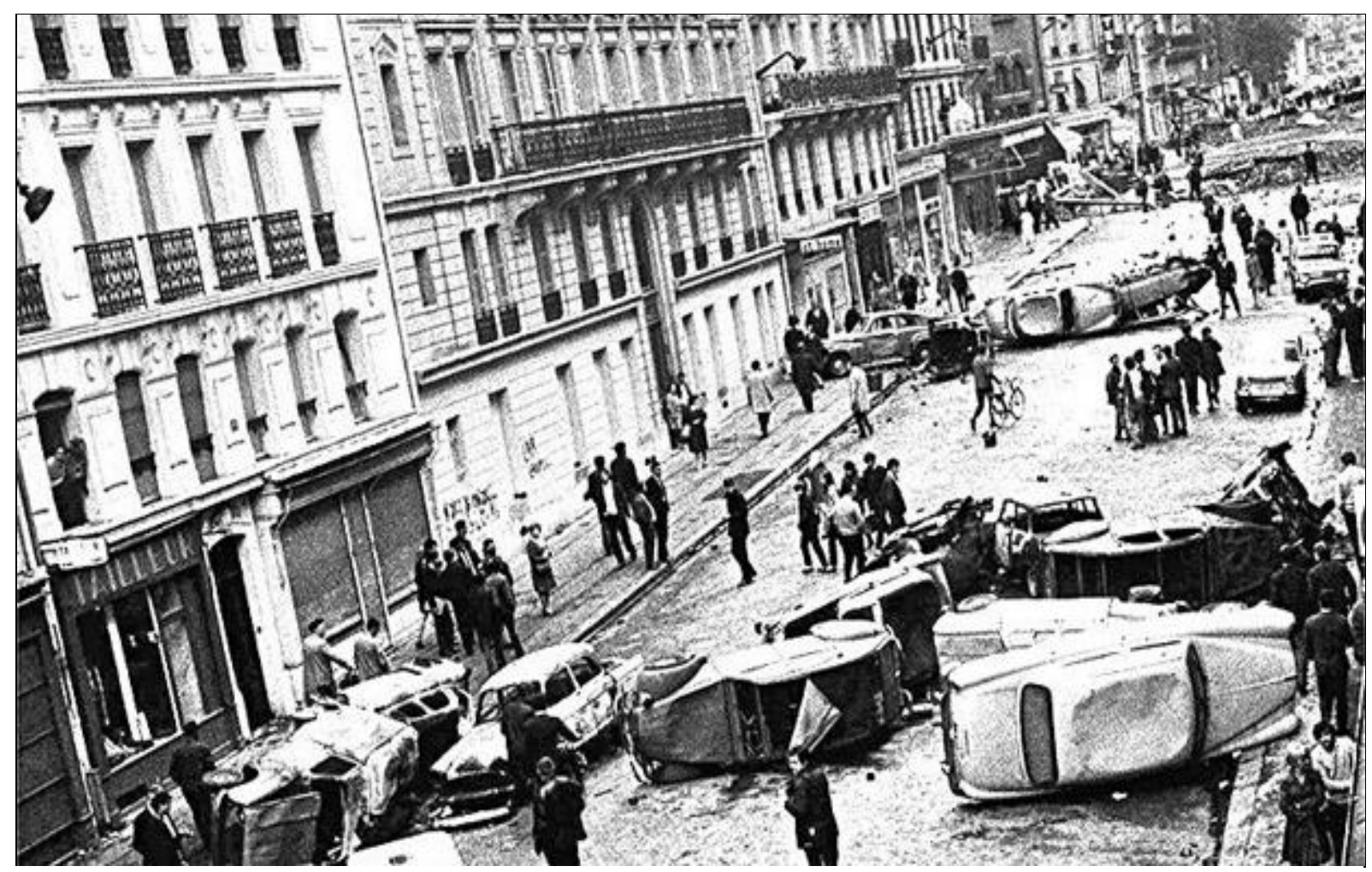

Figura 3 - Manhã do dia 11 de maio de 1968 na Rue Gay-Lussac, após a noite das barricadas.

Fonte: folha.uol.com.br

Estudos Geográficos, Rio Claro, 17: 134-159, jan./jun. $2019 \quad$ (ISSN 1678-698X) http://www.periodicos.rc.biblioteca.unesp.br/index.php/estgeo 
No Brasil, o maio de 1968 aparecia como um caos, na França os intelectuais permaneciam divididos, não era mais possível se manter neutro a situação, a ausência de afirmação partidária dos estudantes, apesar de ideologicamente estarem mais à esquerda, confundia a opinião pública. Sartre que participava ativamente do movimento, seja como intelectual engajado, uma espécie de "tutor" (MORIN, 2018), mas também por ir as ruas distribuir panfletos e engrossar as fileiras com os jovens, não se furtava de expor suas opiniões, dizia o filósofo no mês de junho de 1968 "O que eu condeno em todos aqueles que insultaram os estudantes é não ter visto que estes exprimiam uma reivindicação nova, que era a da soberania" (SARTRE, 1968). Em meio a afirmação da liberdade e da soberania ressaltada por Sartre e da autonomia e do espírito comunitário revelado por Morin, fato é que a dimensão cultural parece ter abarcado o movimento e ter inventado outra maneira de se protestar e tomar as ruas, com causas específicas que sempre foram interpretadas como individuais, mas que naquele momento daria um passo rumo a outra juventude.

Pretendo agora, com todo o risco que é inerente a esta ação, trazer alguns apontamentos de outros dois acontecimentos que tomaram as ruas, as jornadas de junho de 2013 no Brasil e o movimento dos coletes amarelos novamente na França em 2018 e ainda está em curso neste ano de 2019. Começarei evidenciando o que há de proximidade entre o maio de 1968 e o junho de 2013.

\section{JOVENS DE TODAS AS CORES UNÍ-VOS: AS JORNADAS DE JUNHO}

O artigo $19^{\circ}$ da Declaração Universal dos Direitos Humanos expressa "Toda pessoa tem direito à liberdade de opinião e expressão; este direito inclui a liberdade de, sem interferência, ter opiniões e de procurar, receber e transmitir informações e ideias por quaisquer meios e independentemente de fronteiras." Ao largo da crítica que no início deste texto faço em relação ao caráter individualista e a noção de universalidade que expressa a DUDH, é nela também que se pode esclarecer os conflitos e os desentendimentos sobre o papel da rua. A rua é o lugar por excelência do ir e vir, e também o lugar de se expressar. Assim como em 1968 na França o que se viu foi uma avalanche de críticas aos jovens que estariam fazendo algazarras inconsequentes e não sabiam onde queriam ir, no Brasil no mês de junho de 2013 parece ter repetido em parte o mesmo fluxo de críticas.

As jornadas de junho trouxeram em sua multifacetada atitude e em sua afirmação idiossincrática componentes inéditos nas formas de luta que se expressaram nas ruas brasileiras ao longo do processo de redemocratização. Se as diretas já, os "caras pintadas" e os tradicionais protestos geralmente organizados pelas centrais sindicais traziam inimigos bem nítidos, no caso das jornadas de junho de 2013 o que se viu pelas ruas foi o desfilar da diversidade. Em 1968, Cohn-Bendit já respondia sobre esta característica e de forma bem-humorada ela afirmava:

Todos ficariam tranquilos, particularmente Pompidou ${ }^{5}$, se organizássemos uma festa e anunciássemos: "Todas essas pessoas aqui são nossas agora. Aqui estão nossos objetivos e é assim que vamos alcançá-los". Eles saberiam com quem estavam lidando e

\footnotetext{
${ }^{5}$ Trata-se de Georges Pompidou, primeiro ministro francês durante o maio de 1968 e assumiu a presidência em 1969 quando Charles de Gaulle renunciou.

Estudos Geográficos, Rio Claro, 17: 134-159, jan./jun. $2019 \quad$ (ISSN 1678-698X) http://www.periodicos.rc.biblioteca.unesp.br/index.php/estgeo
} 
como combatê-los. Eles não precisariam mais enfrentar "anarquia", "desordem", "efervescência incontrolável" (COHN-BENDIT, 1968).

As palavras desordem, anarquia e descontrole compareceu aos jornais brasileros durante todo o mês de junho de 2013 e seguiu ainda depois. De fato a forma como tudo começou em nada poderia carregar nitidamente o que veio a acontecer naquele período. Assim como em 1968 o início se deu por um motivo específico que desencadeou e insuflou o movimento, em 2013 no Brasil a causa inicial era uma singela contestação de aumento de passagem de ônibus na cidade de São Paulo. Cohn-Bendit chega a afirmar que a ocupação policial da Sorbonne teria sido um erro grotesco das forças oficiais, e que teria despertado os jovens de suas posições acomodadas. Já se sabia dos acontecimentos em abril na Universidade de Columbia em Nova York e Berkeley em 19646 ${ }^{6}$, também ecoava notícias do Brasil "As lutas de estudantes do Brasil contra a ditadura foram comentadas na França, no início de 1968." (THIOLLENT, 1998, 66), além dos diversos movimentos que estavam em gestação pelo mundo. Algo de mesma natureza em certa medida também se sentia entre os jovens no Brasil em 2013, neste sentido o próprio Alain Touraine parece ter percebido algo semelhante, afirma Touraine:

[...] os chamados movimentos sociais mudaram do social para o cultural. Este é um fenômeno importante que foi amplamente confirmado mais recentemente. Estou pensando na Primavera Árabe, ou nos estudantes chilenos de 2011. Isso já era verdade em 1968, na França e em 1964 em Berkeley (TOURAINE, 2018).

O que ocorreu em junho de 2013 no Brasil possui suas características particulares, apesar de guardar semelhança com o maio de 1968 na França, o decantar do tempo ainda não se completou, em 2019 pode-se perceber alguns refluxos dos acontecimentos das jornadas de junho. $O$ que pretendo é exatamente seguir os passos metodológicos adotados para tratar do maio de 1968, buscando entrevistas e testemunhos de personagens reais das ruas e interpretações vindas também da temperatura dos acontecimentos e alguns com certa distância dos fatos. A presidenta da União Nacional dos Estudantes, Vic Barros, eleita exatamente em junho de $2013 \mathrm{fez}$ ao site da UNE a seguinte síntese sobre do movimento, no final do mesmo ano:

Acho que as manifestações mostraram a grande expectativa da população brasileira pela ampliação da cidadania, dos direitos sociais e escancararam os imensos problemas nas grandes cidades, como é o caso do acesso ao transporte e à saúde pública de qualidade (BARROS, 2013).

Novamente a cidade está no centro das angústias, a mobilidade dos mais pobres parece ter sido o fio condutor do levante, contra os 20 centavos de aumento na tarifa de ônibus. A norma foi contestada, a rua foi ocupada e o tabuleiro político ideológico sofre um abalo de proporções que ninguém conseguiria prever naquele momento. A Socióloga Ângela Alonso, em entrevista concedida a BBC propõe uma

\footnotetext{
${ }^{6}$ Apesar do movimento de Columbia em abril de 1968 ter tido uma relação mais direta com o que ocorreu em maio na França, é preciso dizer que já em 1964 na Universidade de Berkeley, na Califórnia, uma mobilização estudantil já cobrava o direito de organizar atividades políticas no campus da universidade, algo que era proibido desde 1950.

Estudos Geográficos, Rio Claro, 17: 134-159, jan./jun. 2019 (ISSN 1678-698X) http://www.periodicos.rc.biblioteca.unesp.br/index.php/estgeo
} 
leitura a partir de três interpretações. A primeira, afirma Alonso, frisou em tentar entender as causas "[...] Apareceu muita coisa sobre a crise de representação, a ascensão de novos grupos sociais, como uma nova classe média, ou seja, explicações que lidaram com a raiz de junho", uma segunda leitura ainda se vinculou a forma tradicional de interpretação dos movimentos sociais e se fixaram nos atores envolvidos, para ela "Muita gente falou no Movimento Passe Livre (MPL), por exemplo, como se a crise pudesse ser circunscrita a um único ator.", e ainda há uma terceira leitura, da qual Alonso corrobora, que "[...] tenta entender o processo. Ela tenta mostrar como vão aparecendo novos atores e novos temas, na medida em que o ciclo do protesto vai se desdobrando, sem que seja possível circunscrevê-lo a uma só bandeira" (ALONSO, 2018). A junção de grupos sociais ofereceu tentáculos ainda maiores para as manifestações, jovens pobres da periferia, universitários de classe média, professores, trabalhadores, parte da burguesia e gente de muitas faces estavam nas ruas em 2013, não se sabia quem estava no comando e nem para onde iam. Os pesquisadores brasileiros, assim como na França em 1968 não conseguiam fechar questão sobre o levante, para Breno Brigel, em entrevista concedida ao Nexo Jornal em 2018:

Junho de 2013 marcou um antes e um depois na trajetória dos protestos do Brasil contemporâneo. Após a emergência de um ciclo de protestos tão significativo, os movimentos iniciadores viram-se superados por outros atores que se uniram ao ciclo para fazer suas próprias reivindicações, sem necessariamente manter os laços com aqueles que desencadearam as manifestações e/ou repetir suas agendas, cultura organizacional, referências ideológicas e formas de ação (BRIGEL, 2018).

O não alinhamento político partidário e em certa medida também ideológico propositivo está na base não linear dos dois movimentos, algo que possibilita diversos entendimentos. O que ocorre é que diferentemente dos movimentos sociais sindicalizados ou partidários, as jornadas de junho de 2013 se conectam com modalidades mais contemporâneas de atitude urbana e de contestação, algo se alinha com a ideia de uma sociedade de autores, vinda catapultada pelas redes sociais digitais, com dinâmicas mais individualizadas que despertam outras formas de participação. Moysés Pinto Neto em entrevista concedida ao IHU on-line também em 2018 sintetiza esta característica afirmando que "Junho conseguiu produzir um entusiasmo inédito, uma espécie de pulsão de vida que chamava ao engajamento" (NETO, 2018), havia uma sensação de que o "gigante havia acordado", de seu berço esplêndido.

Manifestar em 2013 era uma determinação geracional, o jovem ainda não tinha tomado as ruas de forma generalizada, o inesperado foi a provocação que se seguiu em direção aos adultos que estavam fora das ruas desde o impeachment de Fernando Collor de Melo e o movimento dos caras-pintadas ${ }^{7}$. Havia um estranhamento entre as pessoas, a mídia não sabia como caracterizar o movimento, a falta de propostas claras, em conjunto com o questionamento em relação a todos os partidos políticos e também aos sindicatos era algo inusitado em meio a um país que iria as urnas no ano seguinte para escolher um novo presidente. Brigel ressalta que "[...] junho sobretudo foi um momento de abertura societária no país, com

\footnotetext{
${ }^{7}$ Movimento em que os jovens foram para as ruas com as caras pintadas em dois riscos, amarelo e verde contra o presidente do Brasil eleito em 1989, após mais de 20 anos de ditadura civil-militar. Fernando Collor de Melo que sofreu o processo de impeachment por corrupção em 1992.

Estudos Geográficos, Rio Claro, 17: 134-159, jan./jun. $2019 \quad$ (ISSN 1678-698X) http://www.periodicos.rc.biblioteca.unesp.br/index.php/estgeo
} 
protestos que foram muito além dos movimentos organizados, chegando a indivíduos que antes não se mobilizavam (ou não estavam organizados) e à sociedade como um todo" (BRIGEL, 2018).

A polaridade esquerda e direita não se organizou dentro das manifestações de junho de 2013, os manifestantes vindos das redes sociais, após o processo de descolamento da raiz inicial do Movimento Passe Livre, estavam agora transformando seus posts em cartazes individuais, viu-se menos faixas do que cartazes nas manifestações (Figura 4), havia algo que além de individualista era também hedonista, pairava um prazer em estar na rua.

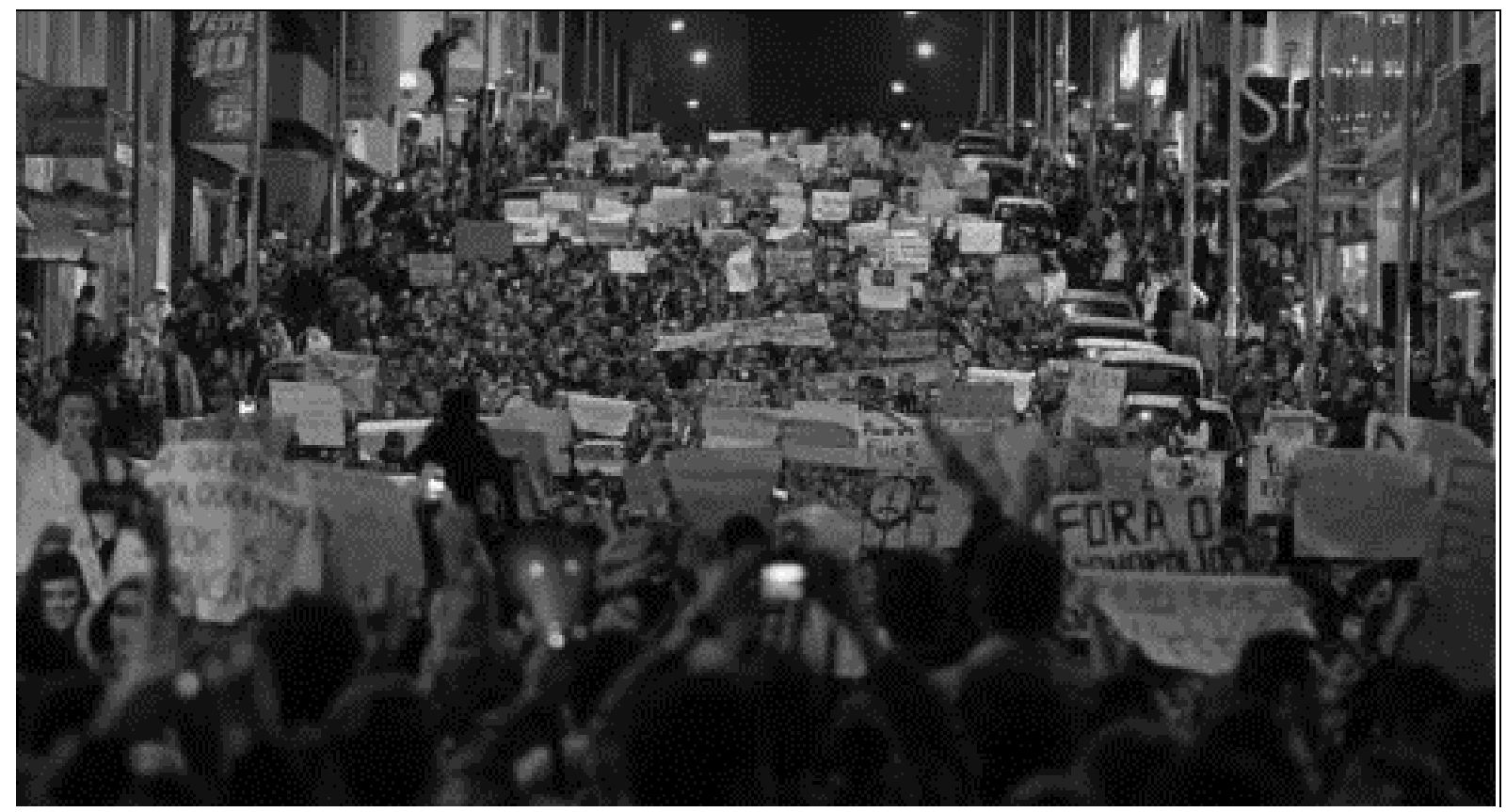

Figura 4 - Manifestantes em São Paulo em junho de 2013, levantando seus cartazes de maneira individual.

Fonte: psicanaliseedemocracia.com.br

Junho de 2013, assim como maio de 1968 também experimentou sua fase mais difícil, com divisão da opinião pública e escalada da violência policial, as figuras de jovens com os rostos tampados, com máscaras e portando escudos ainda era utilizada de forma tímida em alguns pequenos protestos e inédita nas manifestações brasileiras de grande porte, "Em junho, as pessoas se referiam ao "grupo black bloc" ou "aos black blocs" como se fossem uma comunidade com identidade própria e que, assim, seria possível rastrear e isolar essas pessoas (Alonso, 2018). A polícia inicialmente não sabia como se portar e se equivocou em diversas manifestações aumentando a violência e dividindo a opinião pública, aos poucos foi ficando claro que se tratava de uma tática e que "os black blocs" (Figura 5) funcionavam na verdade como uma linha de defesa contra a polícia e ataque aos símbolos do capitalismo internacional como bancos, redes de fast food e também símbolos do estado. Aparecia de maneira mais evidente os autogestionários e a origem anarquista da tática. A surpresa maior se deu pela percepção que os manifestantes outrora mais pacíficos passaram a ter identificação com a tática black bloc, algo ainda mais incompreensível, pois "O que se viu, sobretudo no final das manifestações de junho, foi um monte de gente colocando um lenço no rosto e "virando" black bloc. [...]. Como é uma tática, qualquer um que está na rua pode falar: 'Hoje eu vou fazer isso também'” (Alonso, 2018).

Estudos Geográficos, Rio Claro, 17: 134-159, jan./jun. 2019 (ISSN 1678-698X) http://www.periodicos.rc.biblioteca.unesp.br/index.php/estgeo 
Como a tática black bloc surgiu apenas em 1980 na Alemanha, o que ocorreu na Rua Gay-Lussac no dia 10 de maio de 1968 na França não segue o mesmo viés de acontecimentos. Se no Brasil a tática black bloc teve uma ligação com espírito anarquista, autogestionário e uma causa, mesmo que de difícil compreensão pela burguesia, os quebradores franceses, os casseurs, veem de outra experiência existencial. Paulo Cesar da Costa Gomes, em seu livro "A condição Urbana" afirma que "[...] estes jovens casseurs ${ }^{8}$ são identificados como habitantes das áreas construídas nos anos 60 e 70 para resolver o difícil problema da moradia na aglomeração parisiense" (GOMES, 2002, p. 198).

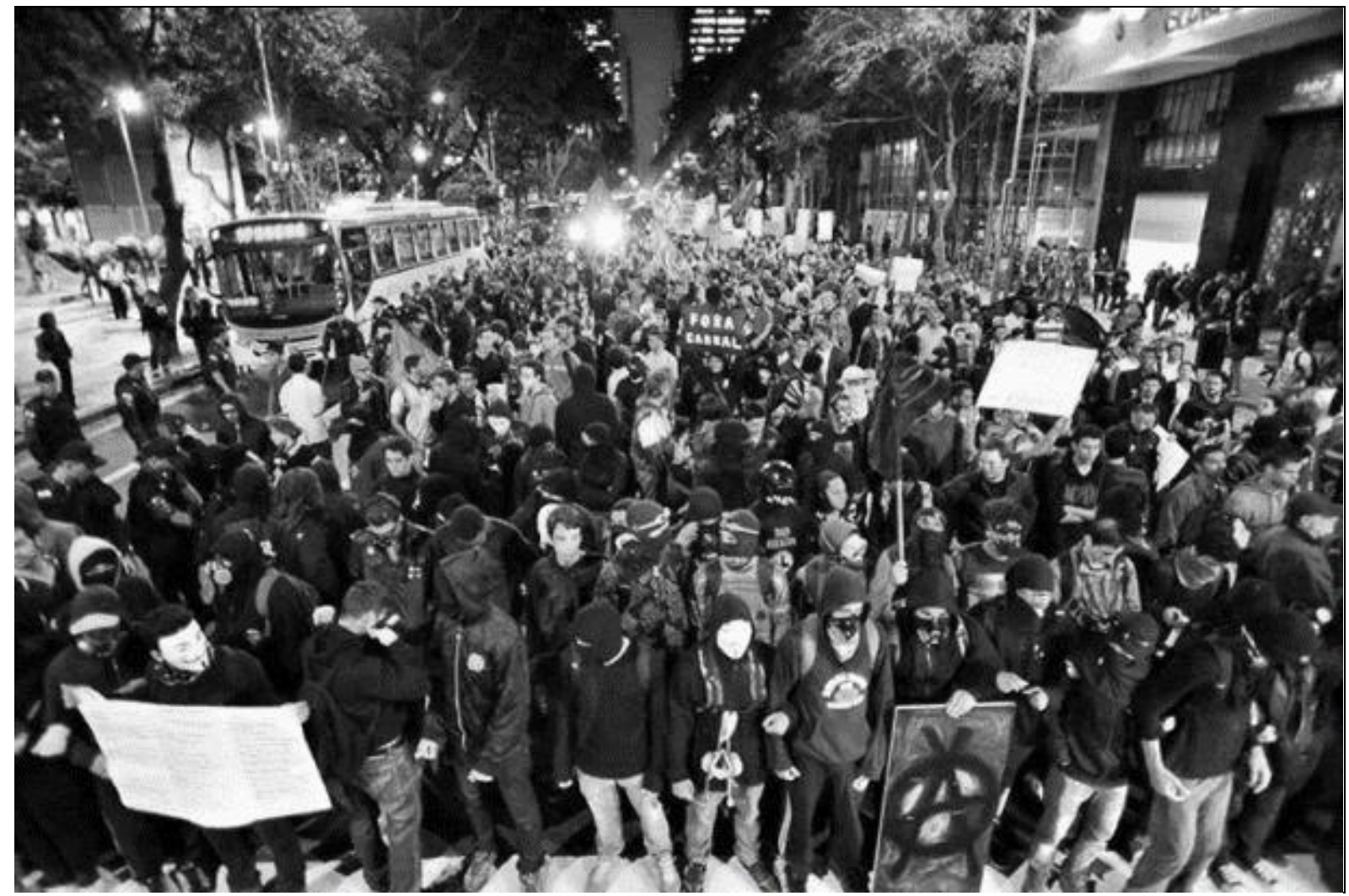

Figura 5 - Com os rostos escondidos, portanto escudos com o símbolo do anarquismo, a tática Black Bloc ganhava adeptos a cada nova manifestação.

Fonte: labeurb.unicamp.br

O vínculo com 1968 é intenso, novamente a reforma urbana toca o fundo da existência dos moradores da cidade, deslocados em nome de uma Paris melhor e mais bonita para usufruto da burguesia, de tempos em tempos eles saem as ruas e quebram e colocam fogo em automóveis. A disputa entre caminhantes e motoristas está também aqui escondida, Paris teria que ter levado mais a sério os ensinamentos de Jane Jacobs.

As manifestações de rua variavam entre o sentimento de paz e união até o de revolta e angústia, não se saia ileso das ruas em 2013 e também não era possível ser indiferente as ruas em 1968, algo que parece estar em curso novamente na França, com roupagens e demandas distintas, através do movimento dos coletes amarelos, que tratarei em seguida.

\footnotetext{
${ }^{8}$ Quebradores.

Estudos Geográficos, Rio Claro, 17: 134-159, jan./jun. $2019 \quad$ (ISSN 1678-698X) http://www.periodicos.rc.biblioteca.unesp.br/index.php/estgeo
} 


\section{OS SENTIDOS FUGIDIOS DA CONQUISTA DAS RUAS: OS COLETES AMARELOS}

A singeleza da origem dos movimentos aqui tratados, em comparação com a amplitude que tomaram ao ocupar as ruas é algo que demonstra a capacidade aglutinadora que a indignação é capaz. Cohn-Bendit afirma que uma das vezes, entre as várias, em que a polícia entrou na Universidade de Nanterre que teria despertado os jovens para se levantarem. Algo que só foi possível pois já estava em ação, sutilmente, uma força contra a condição existencial instalada entre os estudantes. Da mesma forma, um aumento de passagem, entre outros tantos, teria despertado a vontade de gritar, que também já estava em ato presente entre os usuários mais pobres do transporte público. Algo que, mesmo com representações de classes sociais distintas, navegam na mesma onda da necessidade de não aceitar as imposições dos governantes e das autoridades.

No caso dos gilets jaune, os coletes amarelos ${ }^{9}$, algo ainda mais trivial teria sido o estopim da revolta. Serge, nome fictício de um dos manifestantes, concede uma entrevista à Revista Contretemps em abril de 2019 em que afirma que não diretamente, mas em parte, o movimento dos coletes amarelos teve uma ligação inicial com outro movimento chamado Cólera 10, que tinha a participação efetiva de motociclistas, majoritariamente, contra a redução da velocidade para o limite de $80 \mathrm{~km} / \mathrm{h}$ nas vias secundárias. Para Serge é um movimento multifacetado "[...], mas na verdade a maioria das pessoas na extrema direita, verdadeiros azul-brancovermelho", em alusão as cores da bandeira da França. As ligações iniciais entre os dois movimentos logo se arrefeceram, por questões pouco revolucionárias, "[...] houve grandes movimentos no início, mas assim que as manifestações passaram a ser feitas a pé, e não em motocicletas, passou a ter muito menos pessoas" (SERGE, 2019). Obviamente que não foi suficiente para deflagar toda a revolta, foi preciso também atingir toda a população francesa que necessitava utilizar automóveis próprios, fato mais comum nas cidades menores e em zonas rurais. $O$ valor do diesel na bomba de combustível vinha sofrendo alterações desde 2016, e em janeiro de 2019 a lei orçamentária enviada ao parlamento previa um aumento de 6,5 centavos de euro a mais no preço do diesel, e neste caso o preço do diesel foi o detonador final.

Utilizar automóvel na França não é exatamente sinal de pertencer a uma classe burguesa, nas grandes cidades como Paris, Marselle, Lyon e Toulouse, pode se deslocar facilmente com metrô, ônibus e transportes alternativos, além do fato de o sistema de trem de alta velocidade e demais linhas férreas atenderem muito bem as grandes cidades até as cidades médias, mas não conseguem resolver os problemas de deslocamento e mobilidade entre as pequenas cidades, o que geralmente é feito em automóveis particulares, com alto índice de migração pendular para o trabalho e para a escola. Para o geógrafo Arnaud Brennetot em entrevista para o site Paris Normandie "A dependência dos indivíduos ao automóvel aumenta

\footnotetext{
${ }^{9}$ Apenas para qualificar minha intenção de pesquisa, o propósito, como já foi afirmado anteriormente, é extrair de relatos de pessoas envolvidas, conexões com um espírito do tempo atual, mormente em relação a existência e o papel da rua. Não caberia no escopo deste texto querer já realizar qualquer análise sobre a materialidade histórica destas manifestações dos coletes amarelos. Falar de um movimento ainda em curso é um desafio, afinal de novembro de 2018 até maio de 2019 , momento do fechamento deste texto, já haviam ocorrido 28 sábados de protestos. A intenção de se elaborar reflexões sobre a liberdade, a existência e a rua é o que me interessa, nesta medida a causa inicial do movimento dos coletes amarelos deve ser entendida como muito além dos fatos concretos relatados pelos próprios envolvidos e mesmo por analistas e cientistas que já se encorajam a emitir suas opiniões.

Estudos Geográficos, Rio Claro, 17: 134-159, jan./jun. $2019 \quad$ (ISSN 1678-698X) http://www.periodicos.rc.biblioteca.unesp.br/index.php/estgeo
} 
necessariamente com a distância dos centros urbanos, seja para ir trabalhar ou acessar serviços coletivos: portanto, afeta principalmente as áreas periurbanas" (BRENNETOT, 2018). A questão que o movimento revela é que a distância para percorrer de casa ao local de trabalho, segundo Brennetot aumentou de 1968 à 2011 em 50\% na Normandia, por exemplo, saindo de 11 para $17 \mathrm{~km}$ por trecho diário, distância que devido a especificidade em relação aos transportes nas regiões periurbanas e das pequenas cidades, só foi possível de se cobrir devido ao uso intenso do automóvel. Outro fator revelado por Brennetot resulta da dinâmica do mercado residencial, para ele " [...] diante do aumento dos preços dos imóveis nos centros urbanos, a tentação tem sido grande para se estabelecer em municípios suburbanos sem serviços e acesso ao transporte público" (BRENNETOT, 2018). Fator que também é ressaltado pelo Geógrafo Chistophe Guilluy em entrevista ao site 20 minutes, "Pela primeira vez na história, os grupos de baixa renda não vivem mais onde os empregos são criados. As pessoas se sentem presas em seu território e são obrigadas a utilizarem seus carros" (GUILLUY, 2018). Esta questão do deslocamento é corroborada também pelo sociólogo Benoît Coquard, em entrevista à revista contretemps, para Coquard ao se observar o cotidiano real de uma mãe que vive no campo, por exemplo, teremos uma quantidade de kilometros rodados bem maior que uma mãe que vive na cidade, uma mãe típica, segundo ele, poderá certamente ter que deixar uma criança "[...] no berçário $10 \mathrm{~km}$, outra na escola primária a $15 \mathrm{~km}$ de distância, que então trabalhará em um call center ou hospital 25 km de distância, depois fazer compras no supermercado a 20 km de distância" (COQUARD, 2018).

O que o movimento dos coletes amarelos demonstra é também um embaralhamento ideológico e a ausência de cores partidárias, assim como em 1968 e 2013. A extrema direita participa do movimento a partir de causas próprias e por ter uma presença marcante no meio rural francês, o inusitado é que por vezes aparecem táticas black bloc, considerada de extrema esquerda (Figura 6). O real concreto ainda é evidenciado por se perceber também que estão nas ruas homens e mulheres que sentem na pele o fato de terem suas vidas atingidas pela política liberal de adequação do preço do combustível ao mercado mundial e também pelo chamado "imposto carbono"10, que se traduz na prática como uma taxação maior do diesel, que é o combustível mais usado na França.

\footnotetext{
${ }^{10} \mathrm{O}$ imposto prevê que o diesel receberia maior taxação por ser mais poluente, numa tentativa do governo francês de se alinhar as demandas ambientais, entretanto como a utilização do diesel é maior do que a gasolina na França o peso recai sobre os mais pobres, não os plenamente pobres, mas aqueles das classes médias baixas que conseguem ainda manter um automóvel.

Estudos Geográficos, Rio Claro, 17: 134-159, jan./jun. $2019 \quad$ (ISSN 1678-698X) http://www.periodicos.rc.biblioteca.unesp.br/index.php/estgeo
} 


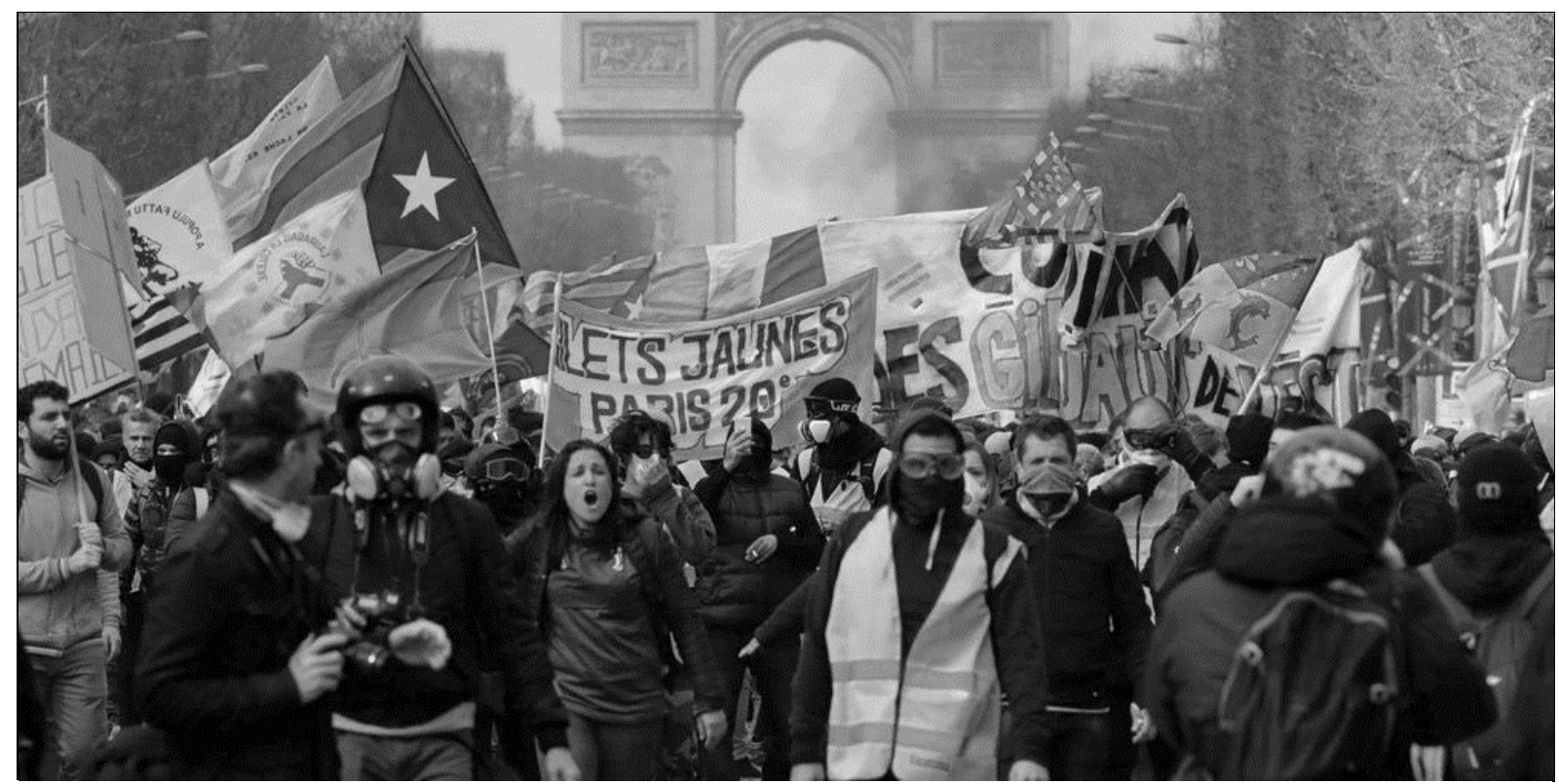

Figura 6 - Manifestantes em Paris vestindo coletes amarelos ao lado de manifestantes vestidos com a indumentária da tática black bloc e diversas bandeiras.

Fonte: sudouest.fr

Para Brennetot "A ideia de que a mobilização de coletes amarelos traduziria uma nova luta de classes entre o rural e o urbano não resiste à análise". (BRENNETOT, 2018). Mais a mobilidade e o deslocamento, mais o automóvel, como objeto de desejo ainda daqueles que não possuem, do que a classe como argumento central para esta nova revolta do povo francês. Para Coquard, este fator faz com que:

O movimento "coletes amarelos" é assim desacreditado por aqueles que, especialmente na pequena ou média burguesia, não veem uma causa nobre porque seria muito relacionado aos interesses individuais, e também porque muitos dos "coletes amarelos" quando questionados, vão contra as greves no serviço público, contra a imigração ${ }^{11}$ e assim por diante. No entanto, o que os fez mobilizar aqui são as reivindicações relacionadas ao poder de compra e, portanto, a distribuição de riqueza (COQUARD, 2018).

Sem partidos políticos envolvidos diretamente e com variantes díspares entre seus participantes os "coletes amarelos" estão ainda em processo de compreensão, para Coquard, é um equívoco buscar entender e criticar os manifestantes a partir da ideia de que seriam individualistas, não sindicalizados e nem organizados em associações, e por representarem classes sociais antagônicas. Esta leitura da esquerda tradicional precisa ter em conta que "[...] em um contexto de condições de vida cada vez mais precárias das classes mais baixas, é importante ter uma 'boa reputação' para escala local" e esta necessidade de buscar os pares e com isso participarem de coletividades amigáveis, nem sempre são compatíveis com os tipos de administração que sindicatos e associações representam e que para ele "[...] tendem a entrar em colapso" (COQUARD, 2018). Mesmo que as causas não sejam exatamente as mesmas, há semelhanças entre os movimentos de 1968, 2013

\footnotetext{
${ }^{11}$ Em entrevista à Revista Contretemps em abril de 2019 Béatrice (Nome fictício), uma manifestante, em relação a imigração afirma que [...] o problema é que estamos trazendo pessoas que não têm nossa cultura, que são mais muçulmanas. Portanto, temos riscos de que essas pessoas um dia se voltem contra nós, fazendo ataques.

Estudos Geográficos, Rio Claro, 17: 134-159, jan./jun. $2019 \quad$ (ISSN 1678-698X) http://www.periodicos.rc.biblioteca.unesp.br/index.php/estgeo
} 
e 2018, que a despeito de olhares mais a direita ou mais a esquerda, se expressam de maneira contundente no que se refere ao distanciamento das formas tradicionais de se fazer política, na dimensão existencial traduzida no cotidiano, na forma de lidar com os deslocamentos pelo território e na atenção dada a dimensão individual como alerta coletivo. Nas considerações finais tratarei de realizar algumas sínteses interpretativas advindas destas aproximações entre os três movimentos e o sentido de liberdade.

\section{CONSIDERAÇÕES FINAIS}

O texto possui como expressões centrais a liberdade, a rua e o poder de se manifestar, de forma geral alcançar conclusões definitivas em ciências humanas e em geografia humana em particular não é tarefa quantitativa em última instância, neste texto, diante do objeto escolhido, as manifestações, reconhecidas aqui como multifacetadas, o exercício conclusivo é ainda mais delicado.

Algumas sínteses, mesmo que sujeitas a ajustes futuros, já são possíveis de se extrair do percurso intelectual aqui tentado. Quanto à liberdade expressa na Declaração Universal dos Direitos Humanos em enfrentamento com a noção de liberdade e existência humana em Sartre é possível dizer que a "autonomia da escolha" que defende o filósofo francês é mais ampla e mais contundente quando o que se pretende é a emancipação do homem. Somando-se esta noção à concepção de responsabilidade sartreana de que o sujeito, enquanto coletividade, assume em seus atos toda a humanidade, é preciso confirmar os limites que a DUDH não consegue alcançar, o limite do humano que carrega a humanidade é para além dos estados.

As reformas urbanas entendidas como instrumentos que visam conter a liberdade nas cidades, assumem o centro das energias catalisadoras e deflagradoras dos levantes populares trabalhados neste texto. A higienização, a gentrificação e a desconexão entre os automóveis e os caminhantes formam em conjunto uma espécie de fundamento urbano que alimenta a indignação das classes médias e baixas das sociedades aqui estudadas. É possível afirmar que os levantes populares de 1968, 2013 e 2018 foram momentos de gritos por mais cidade, mais rua e mais participação urbana.

A França e o Brasil, com disparidades incomensuráveis aparecem neste texto com proximidades bem definidas, seja na caraterização de uma juventude desprovida de horizontes e que se desloca para as ruas, como no Maio de 1968 e nas Jornadas de Junho de 2013, seja no caso da luta por preços mais acessíveis durante o deslocamento, como percebido nas Jornadas de Junho de 2013 e nos "Coletes Amarelos" em 2018 e 2019, ou ainda no descontentamento com as formas tradicionais de formação política e de ação nas cidades, presentes nos três casos estudados.

Algumas divergências ou ligeiras diferenças também podem ser destacadas, em Maio de 1968 na França e em Junho de 2013 no Brasil, as manifestações ocorriam durante a semana, em dia de jornada de trabalho convencional, com intensidades distintas, mas basicamente circunscritas ao próprio mês que nomeia o movimento, no caso dos "Coletes Amarelos", até este momento já foram para as ruas em vinte e oito sábados seguidos, o que na prática significa já seis meses de protestos e manifestações. Não cabe aqui pensar a amplitude dos ganhos e das perdas de cada movimento, entretanto para pensar o papel da rua e da relação entre caminhantes e automóveis, os "Coletes Amarelos" conseguem se relacionar com

Estudos Geográficos, Rio Claro, 17: 134-159, jan./jun. $2019 \quad$ (ISSN 1678-698X) http://www.periodicos.rc.biblioteca.unesp.br/index.php/estgeo 
mais pacificação com os motoristas dos automóveis. É cedo ainda para afirmar, mas nos induz a pensar que esta atitude de se manifestar aos sábados diminui o confronto direto com os usuários das ruas, atrapalham menos o trabalho, e aqui vale ressaltar que já se registra uma diminuição da potência no movimento. Respeitar o trabalho pode neste caso significar uma paciência incompatível com as pautas reivindicadas.

Quanto ao espectro ideológico notou-se que em maio de 1968 as esquerdas ainda tinham mais ascensão ao movimento, mesmo percebendo gritos radicais contra todas as ideologias, no caso das Jornadas de Junho em 2013, a pauta inicial traz a cidade no centro, o transporte público evidenciado nos protestos foi atendido, e posteriormente as demandas extrapolam a cidade e a raiz multifacetada inerente ao movimento vem à tona, despartidarizando e aprofundando na crise de alinhamento institucionalizado, fato que posteriormente não se manteve, pois diversos partidos e aglomerações de cunho partidário foram desdobradas a partir e na esteira de Junho de 2013. No caso dos "Coletes Amarelos", a característica multifacetada é ainda mais entranhada no movimento, desde o princípio houve acomodações ideológicas. A permanência é o caráter multifacetado dos gritos, que figura inclusive no título deste artigo e que em nome da liberdade ocupou as ruas e forjou novas juventudes e movimentou o solo da cultura e da sociedade ocidental.

\section{REFERÊNCIAS}

ALONSO, A. [Entrevista disponibilizada em 13 de junho de 2018, na internet]. 2018. Disponível em: https://www.bbc.com/portuguese/brasil-44310600. Acesso em: 27 de maio de 2019.

ARONSON, R. (2004) Camus e Sartre, o polêmico fim de uma amizade no pósguerra. Rio de Janeiro: Nova Fronteira, 2007.

BADIOU, A. [Entrevista disponibilizada em 27 de março de 2008, na internet] Disponível em: https://www.nonfiction.fr/article-890entretien_avec_alain_badiou_4_sur_mai_68.htm. Acesso em: 28 de maio de 2019.

BARROS, V. [Entrevista disponibilizada sem data especificada, na internet]. 2013. Disponível em: https://une.org.br/2013/12/em-entrevista-presidenta-da-une-apontajuventude-mais-feminista-e-democratica/. Acesso em: 27 de maio de 2019.

BÉATRICE (Nome fictício). [Entrevista disponibilizada em 15 de abril de 2019, na internet]. 2019. Disponível em: https://www.contretemps.eu/entretiens-gilets-jaunestroyes/. Acesso em: 26 de maio de 2019.

BRENNETOT, A. [Entrevista disponibilizada em 26 de novembro de 2018, na internet]. 2018. Disponível em: https://www.parisnormandie.fr/actualites/politique/arnaud-brennetot-geographe--ce-que-revele-lemouvement-des-gilets-jaunes-OM14188251. Acesso: em 28 de maio de 2019.

BRIGEL, B. [Entrevista disponibilizada em 09 de junho de 2018, na internet]. 2018. Disponível em: https:/www.nexojornal.com.br/entrevista/2018/06/09/Como-ler-junho-

Estudos Geográficos, Rio Claro, 17: 134-159, jan./jun. 2019 (ISSN 1678-698X) http://www.periodicos.rc.biblioteca.unesp.br/index.php/estgeo 
de-2013-com-os-olhos-de-2018-segundo-este-pesquisador. Acesso em: 28 de maio de 2019.

COELHO, I. M. A liberdade em Sartre. In: PEIXOTO, A. J. Concepções sobre fenomenologia. Goiânia: Editora UFG, 2003.

COHN-BENDIT, D. Entrevista com Daniel Cohn-Bendit realizada por Jean-Paul Sartre. Le Nouvel Observateur em 20 de maio e 1968. Disponível em: https://bibliobs.nouvelobs.com/idees/20180315.OBS3685/quand-sartre-interviewaitcohn-bendit-dans-I-obs-du-20-mai-1968-un-dialogue-historique.html. Acesso em: 25 de maio de 2019.

COQUARD, B. [Entrevista disponibilizada em 23 de novembro de 2018, na internet]. 2018. Disponível em: https://www.contretemps.eu/sociologie-gilets-jaunes/. Acesso em: 27 de maio de 2019.

DECLARAÇÃO Universal dos Direitos Humanos. Disponível em: https://www.unicef.org/brazil/pt/resources_10133.htm. Acesso: em 23 de jan. 2017.

GOMES, P. C. C. A condição urbana: ensaios de geopolítica da cidade. Rio de Janeiro: Bertrand Brasil, 2010.

GUILLUY, C. [Entrevista disponibilizada em 19 de novembro de 2018, na internet]. 2018. Disponível em: https://www.20minutes.fr/societe/2375331-20181119-giletsjaunes-geographe-christophe-guilluy-france-haut-fait-secession-france-bas. Acesso em: 28 de maio de 2019.

HARVEY, D. (2012) Cidades Rebeldes. São Paulo: Martins, 2014.

JACOBS, J. (1961) Morte e vida de grandes cidades. São Paulo: Martins Fontes, 2017.

LEFEBVRE, Henry. (1968) O direito à cidade. São Paulo: Centauro, 2015

MORIN, E. WIEVIORKA, M.[Entrevista disponibilizada em 12 de março de 2018, na internet] 2018. Disponível em https://journals.openedition.org/socio/3124, Acesso em: 25 de maio de 2019.

NETO, M. P. [Entrevista disponibilizada em 30 de junho de 2018, na internet]. 2018. Disponível em: http://www.ihu.unisinos.br/159-noticias/entrevistas/580105-ointerminavel-junho-de-2013-entrevista-especial-com-moyses-pinto-neto. Acesso em: 28 de maio de 2019.

SARTRE, J.P. LÉVY. B. O testamento de Sartre. Porto Alegre: L\&PM, 1986.

SARTRE, J. P. (1943). O ser e o nada: Ensaio de ontologia fenomenológica (23a ed.). Petrópolis, RJ: Editora Vozes, 1997.

Estudos Geográficos, Rio Claro, 17: 134-159, jan./jun. 2019 (ISSN 1678-698X) http://www.periodicos.rc.biblioteca.unesp.br/index.php/estgeo 
SARTRE, J. P. (1945). O existencialismo é um humanismo. São Paulo: Abril Cultural, 1978 (Os Pensadores).

SERGE (Nome fictício). [Entrevista disponibilizada em 15 de abril de 2019, na internet]. 2019. Disponível em: https://www.contretemps.eu/entretiens-gilets-jaunestroyes/. Acesso em: 26 de maio de 2019.

THIOLLENT, M. Maio de 1968 em Paris: testemunho de um estudante. Tempo Social; Rev. Social. USP, S. Paulo, 10 (2): 63-100, outubro de 1998.

TOURAINE, A. [Entrevista disponibilizada em 16 de março de 2018, na internet]. 2018. Disponível em: https://theconversation.com/entretien-avec-alain-touraine-mai68-lentree-du-monde-dans-une-ere-dominee-par-des-enjeux-culturels-93043.

Acesso em: 30 de maio de 2019.

WALLERSTEIN, I. Columbia 1968: Some Personal Memories. Immanuel Wallerstein Disponível em https://www.iwallerstein.com/columbia-1968-somepersonal-memories/, Acesso em: 29 de maio de 2019. 